\title{
Efficacy and safety of parenteral vitamin D therapy in infants and children with vitamin D deficiency caused by intestinal malabsorption
}

\author{
Sae Bit Yu, MD, \\ Yena Lee, MD, \\ Arum Oh, MD, \\ Han-Wook Yoo, MD, PhD, \\ Jin-Ho Choi, MD
}

Department of Pediatrics, Asan Medical Center Children's Hospital, University of Ulsan College of Medicine, Seoul, Korea
Received: 28 August, 2019

Revised: 29 October, 2019

Accepted: 31 October, 2019

Address for correspondence: Jin-Ho Choi, MD

Department of Pediatrics, Asan Medical Center Children's Hospital, University of Ulsan College of Medicine, 88, Olympic-ro 43-Gil, Songpa-Gu, Seoul 05505, Korea

Tel: +82-2-3010-3991

Tel: +82-2-473-3725

E-mail:jhc@amc.seoul.kr

https://orcid.org/0000-0003-11967826
Purpose: Oral supplementation of vitamin D can be inefficient in patients with vitamin $D$ deficiency caused by intestinal malabsorption. This study investigated the efficacy and safety of parenteral vitamin $D$ supplementation in infants and children with vitamin $\mathrm{D}$ deficiency caused by intestinal malabsorption.

Methods: This study included 11 patients with vitamin D deficiency who were unresponsive to oral vitamin $\mathrm{D}$ or were unable to try oral vitamin $\mathrm{D}$ therapy due to underlying conditions. All patients were treated with weekly intramuscular injection of cholecalciferol 50,000 IU. Radiological findings and biochemical parameters including serum calcium, phosphorus, alkaline phosphatase, 25-hydroxyvitamin $\mathrm{D}_{3}$ $\left(25(\mathrm{OH}) \mathrm{D}_{3}\right)$, and parathyroid hormone levels were reviewed retrospectively.

Results: Underlying diseases included small bowel atresia $(n=3)$, necrotizing enterocolitis $(n=3)$, congenital megacolon $(n=2)$, chronic intestinal pseudoobstruction $(n=1)$, congenital mesenteric band $(n=1)$, and Crohn disease $(n=1)$. Three patients exhibited rickets on X-ray findings. The mean duration of treatment was $4.8 \pm 2.9$ weeks. The alkaline phosphatase levels were decreased from $710 \pm 650$ $\mathrm{IU} / \mathrm{L}$ to $442 \pm 284 \mathrm{IU} / \mathrm{L}(P=0.143)$. The $25(\mathrm{OH}) \mathrm{D}_{3}$ level was increased from $6.0 \pm 3.4 \mathrm{ng} /$ $\mathrm{mL}$ to $50.4 \pm 28.8 \mathrm{ng} / \mathrm{mL}(P=0.008)$ after 3 months. Two patients with rickets showed improved radiologic findings after parenteral treatment.

Conclusion: Parenteral vitamin D therapy was effective and safe in patients with vitamin $\mathrm{D}$ deficiency caused by intestinal malabsorption. Long-term follow-up is needed to establish the efficacy of parenteral vitamin $D$ therapy in a large number of patients.

Keywords: Malabsorption, Rickets, Vitamin D, Vitamin D deficiency

\section{Introduction}

Vitamin D is an important nutrient for absorption of intestinal calcium and phosphorus, ${ }^{1)}$ cellular proliferation and differentiation, muscle function, and immunity. ${ }^{2,3)}$ Vitamin D deficiency can cause rickets in growing children and osteomalacia in adults. ${ }^{4)}$ Deficiency in this vitamin is defined as serum 25-hydroxyvitamin $\mathrm{D}_{3}\left(25(\mathrm{OH}) \mathrm{D}_{3}\right)$ level $<12 \mathrm{ng} / \mathrm{mL}$, while vitamin $\mathrm{D}$ insufficiency is $25(\mathrm{OH}) \mathrm{D}_{3}$ level of $12-20 \mathrm{ng} / \mathrm{mL}$.

Children with vitamin $\mathrm{D}$ deficiency should be treated to prevent hypocalcemia and bone deformity. Several treatment regimens have been proposed to treat vitamin D deficiency in infants and children. ${ }^{5-8)}$ One clinical trial suggested that 2,000 IU of oral ergocalciferol (vitamin $\mathrm{D}_{2}$ ) daily, 50,000 IU of vitamin $\mathrm{D}_{2}$ weekly, or 2,000 IU of cholecalciferol (vitamin $\mathrm{D}_{3}$ ) daily demonstrated the same outcomes in treatment of vitamin D deficiency among infants and toddlers without any complications. ${ }^{7)}$ Another study reported that intramuscular injection of $10,000 \mathrm{IU} / \mathrm{kg}$ of cholecalciferol is a safe and effective therapy for infants and toddlers 
with vitamin D-deficient rickets. ${ }^{9)}$ Recent guidelines have recommended 2,000 IU of vitamin $\mathrm{D}_{3}$ daily or 50,000 IU weekly for 3 months followed by a maintenance amount of $400 \mathrm{IU} /$ day in children younger than 1 year of age. For children older than 1 year, 3,000-6,000 IU of vitamin $\mathrm{D}_{3}$ daily or 150,000 IU weekly are recommended. ${ }^{5)}$

Intestinal absorption of vitamin D occurs primarily in the jejunum and ileum. ${ }^{10)}$ Vitamin D deficiency is recognized as the most prevalent nutrient deficiency in patients with intestinal failure. ${ }^{11)}$ Enteral supplementation of vitamin D was inefficient in patients with vitamin D deficiency caused by intestinal malabsorption, such as cystic fibrosis, short bowel syndrome, inflammatory bowel disease, and intestinal accessory organ dysfunction. ${ }^{11,12)}$ In these cases, parenteral supplementation of vitamin $\mathrm{D}$ is a promising alternative strategy. ${ }^{10)}$ Therefore, this study was performed to investigate the efficacy and safety of parenteral vitamin D supplementation in infants and children with vitamin $\mathrm{D}$ deficiency caused by intestinal malabsorption.

\section{Materials and methods}

\section{Subjects}

This study included 11 patients (8 males and 3 females) with vitamin $\mathrm{D}$ deficiency caused by intestinal malabsorption who were unresponsive to oral vitamin $\mathrm{D}$ supplementation or were unable to try oral vitamin $\mathrm{D}$ therapy due to other underlying conditions. Vitamin D deficiency was defined as $25(\mathrm{OH}) \mathrm{D}_{3}$ level $<12 \mathrm{ng} / \mathrm{mL}^{.5}$

\section{Methods}

Parenteral vitamin $\mathrm{D}_{3}$ (cholecalciferol) was administered intramuscularly at a dosage of 50,000 IU/wk. Parenteral vitamin $\mathrm{D}_{3}$ was switched to oral vitamin $\mathrm{D}_{3}$ at a dosage of $400 \mathrm{IU} /$ day when the serum $25(\mathrm{OH}) \mathrm{D}_{3}$ level rose above $30 \mathrm{ng} / \mathrm{mL}$. Clinical and radiological features, laboratory findings, and duration of vitamin $\mathrm{D}_{3}$ supplementation were reviewed retrospectively. Laboratory investigations included serum calcium, phosphorus, alkaline phosphatase (ALP), $25(\mathrm{OH}) \mathrm{D}_{3}$, and parathyroid hormone (PTH) levels. Height and weight were expressed as a $z$-score for age- and sex-matched Korean youth according to the 2017 Korean National Growth Chart. ${ }^{13)}$

\section{Statistical analysis}

Data were analyzed using IBM SPSS Statistics ver. 21.0 (IBM Co., Armonk, NY, USA). All data are expressed as

Table 1. Demographic findings and underlying diseases of patients with vitamin $D$ deficiency

\begin{tabular}{|c|c|c|c|c|c|c|c|c|c|c|c|c|}
\hline No. & Sex & $\begin{array}{c}\text { Gestational } \\
\text { age (wk) }\end{array}$ & $\begin{array}{l}\text { Birth } \\
\text { weight } \\
\text { (kg) }\end{array}$ & $\begin{array}{l}\text { Underlying } \\
\text { disease }\end{array}$ & Surgery & $\begin{array}{l}\text { Age at } \\
\text { diagnosis of } \\
\text { underlying } \\
\text { disease } \\
\text { (day) }\end{array}$ & $\begin{array}{l}\text { Age at } \\
\text { start of } \\
\text { parenteral } \\
\text { vitamin D } \\
\text { treatment } \\
\text { (mo) }\end{array}$ & $\begin{array}{l}\text { Weight } \\
\text { SDS before } \\
\text { treatment }\end{array}$ & $\begin{array}{l}\text { Height } \\
\text { SDS before } \\
\text { treatment }\end{array}$ & $\begin{array}{l}\text { Current age } \\
\quad(\mathrm{mo})\end{array}$ & $\begin{array}{l}\text { Weight SDS } \\
\text { at current } \\
\text { age }\end{array}$ & $\begin{array}{l}\text { Height SDS } \\
\text { at current } \\
\text { age }\end{array}$ \\
\hline 1 & $M$ & $26^{+5}$ & 0.49 & $\begin{array}{l}\text { Necrotizing } \\
\text { enterocolitis }\end{array}$ & $\begin{array}{l}\text { Small bowel } \\
\text { resection }\end{array}$ & 42 & 1.8 & -11.2 & -12.72 & 55 & -4.97 & -2.66 \\
\hline 2 & $\mathrm{~F}$ & $36^{+6}$ & 3.66 & $\begin{array}{l}\text { Congenital } \\
\text { megacolon }\end{array}$ & Ileostomy & 5 & 2.3 & -1.07 & 0.16 & 57 & -0.56 & -1.59 \\
\hline 3 & $\mathrm{~F}$ & $37^{+6}$ & 3.68 & $\begin{array}{l}\text { Congenital } \\
\text { mesenteric } \\
\text { band }\end{array}$ & Ileostomy & 2 & 5.3 & -0.49 & -0.92 & 7.5 & 0.37 & 0.74 \\
\hline 4 & M & $39^{+5}$ & 3.52 & $\begin{array}{l}\text { Congenital } \\
\text { megacolon }\end{array}$ & Ileostomy & 5 & 4.7 & -5.44 & -2.32 & 12 & -5.24 & 0.95 \\
\hline 5 & M & $25^{+5}$ & 0.41 & $\begin{array}{l}\text { Necrotizing } \\
\text { enterocolitis }\end{array}$ & $\begin{array}{l}\text { Small bowel } \\
\text { resection }\end{array}$ & 8 & 1 & -12.4 & -13.2 & 60 & -3.68 & -3.23 \\
\hline 6 & M & $37^{+5}$ & 3.3 & $\begin{array}{c}\text { Small bowel } \\
\text { atresia }\end{array}$ & $\begin{array}{l}\text { Small bowel } \\
\text { resection }\end{array}$ & 1 & 45 & -0.79 & -0.61 & 112 & -1.8 & -1.05 \\
\hline 7 & M & $37^{+6}$ & 2.8 & Crohn disease & \|leostomy & 170 & 31 & -2.54 & -3.95 & 56 & -2.14 & -3.81 \\
\hline 8 & M & 24 & 0.6 & $\begin{array}{l}\text { Necrotizing } \\
\text { enterocolitis }\end{array}$ & $\begin{array}{l}\text { Small bowel } \\
\text { resection }\end{array}$ & 40 & 1 & -10.67 & -11.15 & 34 & -2.58 & -3.53 \\
\hline 9 & M & $26^{+2}$ & 0.69 & $\begin{array}{c}\text { Small bowel } \\
\text { atresia }\end{array}$ & $\begin{array}{l}\text { Small bowel } \\
\text { resection }\end{array}$ & 30 & 4 & -5.94 & -7.15 & 21 & -3.26 & -5.61 \\
\hline 10 & M & $27^{+4}$ & 0.58 & $\begin{array}{c}\text { Small bowel } \\
\text { atresia }\end{array}$ & $\begin{array}{l}\text { Small bowel } \\
\text { resection }\end{array}$ & 54 & 5.7 & -9.2 & -11.02 & 32 & -4.14 & -4.38 \\
\hline 11 & $\mathrm{~F}$ & $38^{+4}$ & 2.94 & $\begin{array}{l}\text { Chronic } \\
\text { intestinal } \\
\text { pseudo- } \\
\text { obstruction }\end{array}$ & Ileostomy & 20 & 7 & -3.23 & -1.42 & 58 & -0.92 & -0.8 \\
\hline
\end{tabular}

SDS, standard deviation score. 
mean \pm standard deviation values. The Wilcoxon signed rank test was used to compare the baseline and current growth profiles based on $z$-score. Repeated measures analysis of variance was conducted to compare the biochemical parameters at baseline and at 3 months and 6 months following treatment. A $P$-value $<0.05$ was considered statistically significant.

\section{Results}

\section{Baseline characteristics before parenteral vitamin D treatment}

The baseline characteristics of the subjects are summarized in Table 1. Among the 11 patients, 6 (55\%) were preterm infants (gestational age $<37$ weeks), and 5 (45\%) were extremely low birth weight (birth weight $<1,000 \mathrm{~g})$. Four patients $(36 \%)$ underwent ileostomy due to congenital megacolon $(n=2)$, chronic intestinal pseudo-obstruction $(n=1)$, or congenital mesenteric band $(n=1)$. Six patients $(55 \%)$ with small bowel atresia $(n=3)$ or necrotizing enterocolitis $(n=3)$ underwent small bowel resection, resulting in short bowel syndrome. The remaining 1 patient (9\%) was diagnosed with Crohn disease at the age of 5 months. This patient underwent ileostomy and was recurrently admitted for nutritional support due to uncontrolled disease. The median age at the time of the diagnosis of any underlying diseases was 20 days (range, $1-170$ days).

Oral cholecalciferol at 2,000 IU/day was administered to 8 patients $(73 \%)$ before parenteral vitamin $\mathrm{D}_{3}$. The median duration of oral vitamin $\mathrm{D}_{3}$ therapy prior to parenteral vitamin $\mathrm{D}_{3}$ was 2.5 months (range, 20 days to 16 months). The other 3 patients were not able to eat anything including medication because of their underlying condition such as feeding intolerance and bowel adhesion after surgery. The mean $25(\mathrm{OH})$ $\mathrm{D}_{3}$ level before and after oral vitamin $\mathrm{D}_{3}$ therapy was $9.8 \pm 7.6$ $\mathrm{ng} / \mathrm{mL}$ and $6.0 \pm 3.4 \mathrm{ng} / \mathrm{mL}$, respectively $(P=0.263)$. The mean ALP level increased from $605 \pm 303 \mathrm{IU} / \mathrm{L}$ (range, 333-1,082 IU/ $\mathrm{L}$ ) to $710 \pm 650 \mathrm{IU} / \mathrm{L}$ (range, $237-2,353 \mathrm{IU} / \mathrm{L}$ ) after oral vitamin

$\mathrm{D}_{3}$ replacement; however, there was no statistical significance $(P=1.00)$. All patients received nutritional support via parenteral nutrition.

\section{Effect of parenteral vitamin D treatment}

The median age at the start of parenteral vitamin $\mathrm{D}_{3}$ supplementation was 3.9 months (range, 1-45 months). The height and weight standard deviation scores (SDSs) before parenteral vitamin $\mathrm{D}_{3}$ treatment were $-3.6 \pm 5.3$ and $-5.4 \pm 4.5$, respectively. The serum calcium, phosphorus, and ALP levels were $9.2 \pm 0.5 \mathrm{mg} / \mathrm{dL}, 4.8 \pm 1.9 \mathrm{mg} / \mathrm{dL}$, and $710 \pm 650 \mathrm{IU} / \mathrm{L}$ (range, 237-2,353 IU/L), respectively. Five patients (45\%) showed elevated ALP level. Initial serum $25(\mathrm{OH}) \mathrm{D}_{3}$ and PTH levels before parenteral vitamin $\mathrm{D}$ treatment were $6.0 \pm 3.4 \mathrm{ng} / \mathrm{mL}$ and $145 \pm 186 \mathrm{pg} / \mathrm{mL}$ (range, $11.3-508 \mathrm{pg} / \mathrm{mL}$ ), respectively. Five patients (45\%) had elevated serum PTH level at baseline (reference range, $10-65 \mathrm{pg} / \mathrm{mL}$ ) (Table 2). Three of those (27.2\%) (subjects 1,8, and 9) with elevated serum PTH showed X-ray findings of rickets, such as flaring of the distal end of the radius, ulna, and phalanges and bowing of both femurs. Three patients

Table 3. 25-Hydroxyvitamin $\mathrm{D}_{3}$ levels $(\mathrm{ng} / \mathrm{dL}$ ) during treatment of parenteral vitamin $\mathrm{D}_{3}$

\begin{tabular}{lcccc}
\hline No. & Baseline & At 1 month & At 3 months & At 6 months \\
\hline 1 & 4.9 & 52.2 & 23 & 55.2 \\
2 & 4.9 & 3.5 & 29.3 & 37.2 \\
3 & 3.5 & 17.8 & 36.5 & NA \\
4 & 2.7 & 20.4 & 67.8 & NA \\
5 & 3.2 & 63.9 & 91.1 & 121 \\
6 & 3.2 & NA & 12.9 & 18.3 \\
7 & 11.6 & 34 & 58.4 & 69.8 \\
8 & 5.8 & 25.5 & 45.2 & 48.9 \\
9 & 10.6 & 36.2 & 107 & 72.1 \\
10 & 4.4 & 17.3 & 48.6 & NA \\
11 & 11.3 & NA & 34.1 & 23.6 \\
Mean \pm SD & $6.0 \pm 3.4$ & $30.1 \pm 18.8$ & $50.4 \pm 28.8$ & $55.7 \pm 32.8$ \\
\hline NA, not assessed; SD, standard deviation.
\end{tabular}

Table 2. Baseline laboratory findings and X-rays in patients with vitamin D deficiency

\begin{tabular}{|c|c|c|c|c|c|c|}
\hline No. & $\begin{array}{l}\text { Calcium } \\
(\mathrm{mg} / \mathrm{dL})\end{array}$ & $\begin{array}{c}\text { Phosphorous } \\
\text { (mg/dL) }\end{array}$ & $\begin{array}{c}\text { Alkaline phosphatase } \\
\text { (IU/L) }\end{array}$ & $\begin{array}{c}\text { 25-Hydroxyvitamin } \mathrm{D}_{3} \\
\text { (ng/dL) }\end{array}$ & $\begin{array}{l}\text { Parathyroid hormone } \\
(\mathrm{pg} / \mathrm{mL})\end{array}$ & Rickets \\
\hline 1 & 8.6 & 5.8 & 450 & 4.9 & 235 & Yes \\
\hline 2 & 9.4 & 6.5 & 251 & 4.9 & 11.3 & No \\
\hline 3 & 9.1 & 4.9 & 344 & 3.5 & 52.8 & No \\
\hline 4 & 9.9 & 4.4 & 396 & 2.7 & 18.3 & No \\
\hline 5 & 9.6 & 4.5 & 549 & 3.2 & NA & No \\
\hline 6 & 8.4 & 3.8 & 537 & 3.2 & 72.1 & No \\
\hline 7 & 8.9 & 4.4 & 269 & 11.6 & 10.4 & No \\
\hline 8 & 9.8 & 2.8 & 2353 & 5.8 & 150 & Yes \\
\hline 9 & 9.4 & 3 & 1330 & 10.6 & 508 & Yes \\
\hline 10 & 9.5 & 9.5 & 1103 & 4.4 & 117 & No \\
\hline 11 & 8.7 & 3.6 & 237 & 11.3 & 13.6 & No \\
\hline Mean士SD & $9.2 \pm 0.5$ & $4.8 \pm 1.9$ & $710 \pm 649$ & $6.0 \pm 3.4$ & $145 \pm 186$ & \\
\hline
\end{tabular}

$\mathrm{NA}$, not assessed; SD, standard deviation. 
(subjects 1,7 , and 8 ) had a history of fracture of forearm or lower leg.

All patients were treated with 50,000 IU of parenteral vitamin $\mathrm{D}_{3}$ weekly. The duration of treatment was $4.8 \pm 2.9$ weeks (range, 1-9 weeks). Serum calcium, phosphorus, and ALP levels were not significantly changed during parenteral vitamin $\mathrm{D}_{3}$ therapy (Fig. 1). The mean ALP level decreased from 710 $\pm 650 \mathrm{IU} / \mathrm{L}$ (range, 237-2,353 IU/L) to 442 $\pm 284 \mathrm{IU} / \mathrm{L}$ (range, 236-1,080 $\mathrm{IU} / \mathrm{L})$, but there was no statistical significance $(P=0.143)$. The $25(\mathrm{OH}) \mathrm{D}_{3}$ level was increased from $6.0 \pm 3.4 \mathrm{ng} / \mathrm{mL}$ to $50.4 \pm 28.8$ $\mathrm{ng} / \mathrm{mL}$ after 3 months of treatment $(P=0.008)$ and to $55.7 \pm 32.8$ $\mathrm{ng} / \mathrm{mL}$ at 6 months (Table 3). The intact PTH level decreased from $119 \pm 155 \mathrm{pg} / \mathrm{mL}$ (range, $11.3-508 \mathrm{pg} / \mathrm{mL}$; median, 94 $\mathrm{pg} / \mathrm{mL}$ ) to $37 \pm 26 \mathrm{pg} / \mathrm{mL}$ (range, $10.8-47.6 \mathrm{pg} / \mathrm{mL}$; median, $27.6 \mathrm{pg} / \mathrm{mL})(P=0.209)$. However, PTH level normalized after parenteral vitamin $\mathrm{D}_{3}$ treatment in 5 patients with high PTH level $(P=0.043)$.

Six patients maintained normal $25(\mathrm{OH}) \mathrm{D}_{3}$ level with 400 $\mathrm{IU} /$ day of oral vitamin $\mathrm{D}_{3}$ therapy after parenteral vitamin $\mathrm{D}_{3}$ therapy for a mean duration of $5.0 \pm 2.8$ weeks (range, 2-9 weeks). In subject 7, who had Crohn disease, the serum $25(\mathrm{OH})$ $\mathrm{D}_{3}$ level was $>30 \mathrm{ng} / \mathrm{mL}$ after 1 month of parenteral vitamin $\mathrm{D}_{3}$ therapy. However, parenteral vitamin $\mathrm{D}_{3}$ therapy was continued because of the patient's poor general condition and preference
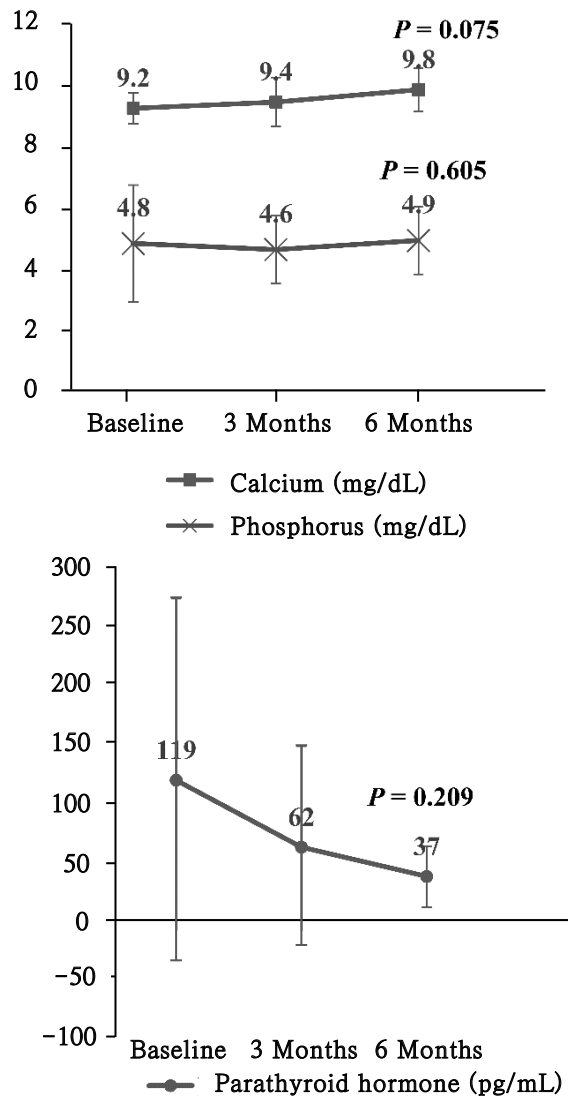

for parenteral therapy. Two patients (subjects 6 and 8) were treated with oral cholecalciferol 2,000 IU/day due to low serum $25(\mathrm{OH}) \mathrm{D}_{3}$ level, osteopenia, or high ALP level. Subject 1 was diagnosed with necrotizing enterocolitis, and subject 9 had small bowel atresia; neither required further treatment with vitamin $\mathrm{D}_{3}$.

Among the 3 patients with rickets (subjects 1, 8, and 9), 2 ( 1 and 9) showed improved radiologic findings following parenteral treatment. The remaining patient (8) with short bowel syndrome due to necrotizing enterocolitis exhibited slight improvement in the flaring of the distal end of the radius, ulna, and phalanges after treatment, but osteopenia was still visible upon X-ray on the last day of follow-up.

The median current age on the last day of follow-up was 55 months (range, 7.5-112 months). Height and weight SDSs increased from $-3.6 \pm 5.3$ to $-2.7 \pm 2.1(P=0.026)$ and from $-5.4 \pm 4.5$ to $-2.6 \pm 1.8(P=0.013)$, respectively. There were no adverse effects of high-dose parenteral therapy, such as hypercalcemia, hyperphosphatemia, or hungry bone syndrome.

\section{Discussion}

This study demonstrated that parenteral vitamin $\mathrm{D}_{3}$ treatment was safe and effective in infants and children with vitamin
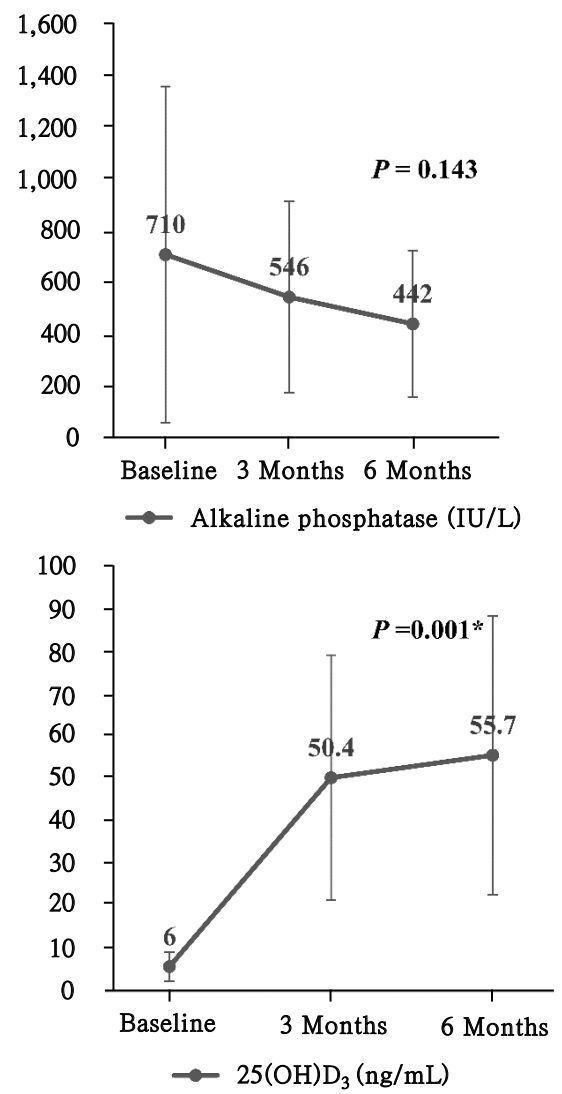

Fig. 1. Laboratory data obtained from patients being treated with parenteral vitamin $\mathrm{D}_{3} .25(\mathrm{OH}) \mathrm{D}_{3}$, 25-hydroxyvitamin $\mathrm{D}_{3}$. 
D deficiency caused by intestinal malabsorption. Oral vitamin $\mathrm{D}_{3}$ treatment was inefficient, and a high dose of parenteral vitamin $\mathrm{D}_{3}$ was required in patients with intestinal failure.

In the present study, all patients were treated with 50,000 IU of parenteral vitamin $\mathrm{D}_{3}$ weekly. ${ }^{6}$ However, various treatment regimens have been proposed to treat vitamin $\mathrm{D}$ deficiency in children, including daily or weekly dosing for varied periods. Several studies were conducted to investigate the efficacy of a single, large dose of oral or intramuscular vitamin $\mathrm{D}$, which was called "stoss therapy," for better convenience and compliance with therapy (Table 4). ${ }^{9,14-16)}$ One retrospective cohort study of 61 children with rickets revealed that a single intramuscular injection of 600,000 IU vitamin $\mathrm{D}_{3}$ and a weekly oral dosage of 60,000 IU vitamin $\mathrm{D}_{3}$ for 10 weeks were equally effective and safe. ${ }^{16)}$ Tannous et al. ${ }^{15)}$ reported that 100,000 IU of oral cholecalciferol weekly for 4 weeks is as safe and effective as 5,000 IU oral cholecalciferol daily for 80 days in children older than 2 years. In contrast, Mittal et al. ${ }^{14)}$ showed that hypercalciuria and hypercalcemia have been more often described in children receiving stoss therapy. Recent guidelines do not recommend stoss therapy as first-line management of vitamin D deficiency; however, stoss therapy might be more practical for those who are noncompliant with daily dosing and those with intestinal malabsorption. ${ }^{5)}$ Previously, 10\%-20\% of patients with intestinal failure were reported to require daily oral vitamin $\mathrm{D}_{3}$ at a dosage of 5,000-6,000 IU. Additionally, a smaller number of patients still do not respond to a high amount of vitamin $\mathrm{D}_{3}{ }^{11)}$ Grenade et al. ${ }^{11)}$ reported that a loading dosage of 20,000-40,000 IU of vitamin $\mathrm{D}_{3}$ once a week, with a daily maintenance dosage of 4,000-6,000 IU/day on the remaining 6 days, has shown efficiency in improving the vitamin $\mathrm{D}$ level of 3 patients with intestinal failure. A prospective study with 40 infants and toddlers in Qatar reported that parenteral injection of a megadose $(10,000 \mathrm{IU} / \mathrm{kg})$ of vitamin $\mathrm{D}_{3}$ for 3 months normalized all the laboratory findings and radiological manifestations. ${ }^{9)}$

Preterm infants have an increased risk of low $25(\mathrm{OH}) \mathrm{D}_{3}$ level compared with full-term infants, ${ }^{17-19)}$ but the association between gestational age and vitamin $\mathrm{D}$ status remains uncertain. The increased prevalence of vitamin D deficiency in preterm infants might be correlated with a lack of sunlight exposure during prolonged hospitalization along with difficulty in adequate enteral feeding. ${ }^{20)}$ Furthermore, preterm infants are at high risk of necrotizing enterocolitis, which can lead to short bowel syndrome and intestinal malabsorption. ${ }^{21)}$

As vitamin $\mathrm{D}$ has an important role in absorption of calcium and phosphorus, only $10 \%-15 \%$ of dietary calcium and $50 \%-60 \%$ of dietary phosphorus are absorbed in patients with vitamin D deficiency. ${ }^{22)}$ Poor absorption of calcium causes hypocalcemia. ${ }^{8)}$ However, no patients in the present study showed hypocalcemia. Low serum ionized calcium level stimulates PTH secretion, causing phosphorus loss in the urine. ${ }^{10)}$ As high PTH level affect bone metabolism by increasing bone turnover, decreased serum PTH level during treatment suggests efficacy of vitamin D therapy. ${ }^{23)}$ All patients with high PTH level demonstrated normalized PTH level after 6 months of parenteral vitamin $\mathrm{D}_{3}$ treatment.

There were some limitations to this study. This investigation was a retrospective study and included a small number of patients at a single medical center. The duration of treatment varied among patients. Therefore, long-term follow-up is needed to establish a precise protocol about the duration and doses of parenteral vitamin $\mathrm{D}_{3}$ treatment.

In conclusion, parenteral vitamin D treatment was safe and effective to prevent rickets in infants and children with vitamin $\mathrm{D}$ deficiency caused by intestinal malabsorption. Long-term follow-up is required to monitor the efficacy and safety of parenteral vitamin D therapy in a large cohort of patients.

\section{Ethical statement}

This study was approved by the Institutional Review Board at Asan Medical Center in Seoul, Korea (2019-1042).

Table 4. Previous studies with stoss therapy

\begin{tabular}{|c|c|c|c|c|c|}
\hline Variable & Mittal et al. ${ }^{14)}(\mathrm{RCT})$ & Tannous et al. ${ }^{15)}(\mathrm{RCT})$ & Mondal et al. ${ }^{16)}(\mathrm{RCT})$ & $\begin{array}{c}\text { Soliman et al.9) } \\
\text { (prospective study) }\end{array}$ & $\begin{array}{l}\text { Grenade et al. }{ }^{11)} \\
\text { (case report) }\end{array}$ \\
\hline Number & 76 & 151 & 61 & 40 & 3 \\
\hline Age & $0.5-5$ Years & 2-16 Years & $0.5-5$ Years & 7-23 Months & 2.3-6.8 Years \\
\hline Duration & 12 Weeks & 4 Weeks & 10 Weeks & 3 Months & 3 Months \\
\hline Dose & $\begin{array}{l}300,000 \text { IU or } 600,000 \text { IU } \\
\text { oral vitamin } D_{3} \text { single } \\
\text { dose }\end{array}$ & $\begin{array}{l}100,000 \text { IU weekly oral } \\
\text { vitamin } D_{3}\end{array}$ & $\begin{array}{l}\text { Group 1: } 600,000 \text { IU as } \\
\text { a single intramuscular } \\
\text { dose } \\
\text { Group 2: } 60,000 \text { IU orally } \\
\text { once a week }\end{array}$ & $\begin{array}{l}\text { 10,000 IU/kg intramuscular } \\
\text { single dose } \\
\text { (maximum 150,000 IU) }\end{array}$ & $\begin{array}{l}20,000-36,000 \text { IU of } \\
\text { vitamin D weekly } \\
\text { followed by } 4,000 \text { IU } \\
\text { on the remaining } 6 \text { days } \\
\text { of the week }\end{array}$ \\
\hline $\begin{array}{l}\text { Underlying } \\
\text { disease }\end{array}$ & Nutritional rickets & $25(\mathrm{OH}) \mathrm{D}_{3}<20 \mathrm{ng} / \mathrm{mL}$ & Nutritional rickets & Vitamin D-deficient rickets & $\begin{array}{l}\text { Vitamin D deficiency with } \\
\text { intestinal failure }\end{array}$ \\
\hline Efficacy & Not effective & Effective & Effective (both group) & Effective & Effective \\
\hline Side effect & $\begin{array}{l}\text { Hypercalcemia in } \\
5 \text { patients }\end{array}$ & None & None & None & None \\
\hline
\end{tabular}

RCT, randomized controlled trial; $25(\mathrm{OH}) \mathrm{D}_{3}, 25$-hydroxyvitamin $\mathrm{D}_{3}$. 


\section{Conflict of interest}

No potential conflict of interest relevant to this article was reported.

\section{Acknowledgements}

This study was supported by the Basic Science Research Program through the National Research Foundation of Korea (NRF) funded by the Ministry of Education (2017R1D1A1B03029638).

\section{References}

1. Bouillon R, Carmeliet G. Vitamin D insufficiency: definition, diagnosis and management. Best Pract Res Clin Endocrinol Metab 2018;32:669-84.

2. Choi HS, Oh HJ, Choi H, Choi WH, Kim JG, Kim KM, et al. Vitamin D insufficiency in Korea--a greater threat to younger generation: the Korea National Health and Nutrition Examination Survey (KNHANES) 2008. J Clin Endocrinol Metab 2011;96:643-51.

3. Maiya S, Sullivan I, Allgrove J, Yates R, Malone M, Brain $\mathrm{C}$, et al. Hypocalcaemia and vitamin D deficiency: an important, but preventable, cause of life-threatening infant heart failure. Heart 2008;94:581-4.

4. Allgrove J, Shaw NJ. A Practical approach to Vitamin D deficiency and rickets. Endocr Dev 2015;28:119-33.

5. Munns CF, Shaw N, Kiely M, Specker BL, Thacher TD, Ozono K, et al. Global consensus recommendations on prevention and management of nutritional rickets. J Clin Endocrinol Metab 2016;101:394-415.

6. Holick MF, Binkley NC, Bischoff-Ferrari HA, Gordon CM, Hanley DA, Heaney RP, et al. Evaluation, treatment, and prevention of vitamin D deficiency: an Endocrine Society clinical practice guideline. J Clin Endocrinol Metab 2011;96:1911-30.

7. Gordon CM, Williams AL, Feldman HA, May J, Sinclair L, Vasquez A, et al. Treatment of hypovitaminosis D in infants and toddlers. J Clin Endocrinol Metab 2008;93:2716-21.

8. Wagner CL, Greer FR; American Academy of Pediatrics Section on Breastfeeding; American Academy of Pediatrics Committee on Nutrition. Prevention of rickets and vitamin $D$ deficiency in infants, children, and adolescents. Pediatrics 2008; 122:1142-52.

9. Soliman AT, El-Dabbagh M, Adel A, Al Ali M, Aziz Bedair EM, Elalaily RK. Clinical responses to a mega-dose of vitamin D3 in infants and toddlers with vitamin D deficiency rickets. J Trop Pediatr 2010;56:19-26.

10. Misra M, Pacaud D, Petryk A, Collett-Solberg PF, Kappy M; Drug and Therapeutics Committee of the Lawson Wilkins Pediatric Endocrine Society. Vitamin D deficiency in children and its management: review of current knowledge and recommendations. Pediatrics 2008;122:398-417.

11. Grenade N, Kosar C, Steinberg K, Avitzur Y, Wales PW, Courtney-Martin G. Use of a loading dose of vitamin d for treatment of vitamin d deficiency in patients with intestinal failure. JPEN J Parenter Enteral Nutr 2017;41:512-6.

12. Yang CF, Duro D, Zurakowski D, Lee M, Jaksic T, Duggan C. High prevalence of multiple micronutrient deficiencies in children with intestinal failure: a longitudinal study. J Pediatr 2011;159:39-44.e1.

13. Kim JH, Yun S, Hwang SS, Shim JO, Chae HW, Lee YJ, et al. The 2017 Korean National Growth Charts for children and adolescents: development, improvement, and prospects. Korean J Pediatr 2018;61:135-49.

14. Mittal H, Rai S, Shah D, Madhu SV, Mehrotra G, Malhotra RK, et al. 300,000 IU or 600,000 IU of oral vitamin D3 for treatment of nutritional rickets: a randomized controlled trial. Indian Pediatr 2014;51:265-72.

15. Tannous P, Fiscaletti M, Wood N, Gunasekera H, Zurynski $\mathrm{Y}$, Biggin A, et al. Safety and effectiveness of stoss therapy in children with vitamin D deficiency. J Paediatr Child Health 2020;56:81-9.

16. Mondal K, Seth A, Marwaha RK, Dhanwal D, Aneja S, Singh R, et al. A Randomized controlled trial on safety and efficacy of single intramuscular versus staggered oral dose of $600000 \mathrm{IU}$ Vitamin D in treatment of nutritional rickets. J Trop Pediatr 2014;60:203-10.

17. Burris HH, Van Marter LJ, McElrath TF, Tabatabai P, Litonjua AA, Weiss ST, et al. Vitamin D status among preterm and full-term infants at birth. Pediatr Res 2014;75:7580 .

18. Natarajan CK, Sankar MJ, Agarwal R, Pratap OT, Jain V, Gupta N, et al. Trial of daily vitamin D supplementation in preterm infants. Pediatrics 2014;133:e628-34.

19. Abrams SA; Committee on Nutrition. Calcium and vitamin $\mathrm{d}$ requirements of enterally fed preterm infants. Pediatrics 2013;131:e1676-83.

20. Monangi N, Slaughter JL, Dawodu A, Smith C, Akinbi HT. Vitamin D status of early preterm infants and the effects of vitamin D intake during hospital stay. Arch Dis Child Fetal Neonatal Ed 2014;99:F166-8.

21. Cole CR, Hansen NI, Higgins RD, Ziegler TR, Stoll BJ; Eunice Kennedy Shriver NICHD Neonatal Research Network. Very low birth weight preterm infants with surgical short bowel syndrome: incidence, morbidity and mortality, and growth outcomes at 18 to 22 months. Pediatrics 2008;122:e573-82.

22. de Boer IH. Vitamin D deficiency. In: Himmelfarb J, Sayegh MH, editors. Chronic kidney disease, dialysis, and transplantation. 3rd ed. Philadelphia (PA): Elsevier Saunders; 2010. p. 115-27.

23. Bowden SA, Robinson RF, Carr R, Mahan JD. Prevalence of vitamin D deficiency and insufficiency in children with osteopenia or osteoporosis referred to a pediatric metabolic bone clinic. Pediatrics 2008;121:e1585-90. 